Удк 93 (477.74)-614.4

DOI: https://doi.org/10.33782/eminak2021.2(34).520

\title{
ЕПІДЕМІОЛОГІЧНА СИТУАЦІЯ В ОДЕСІ У ДОБУ ГЕТЬМАНАТУ (ПО МАТЕРІАЛАМ ОДЕСЬКИХ ГАЗЕТ 1918 р.)
}

\author{
Галина Кязимова \\ Одеський національний морський університет (Одеса, Україна) \\ e-mail: sineva2009@gmail.com \\ ORCID: https://orcid.org/0000-0001-7453-015X
}

На основі аналізу одеської періодичної преси 1918 року розкрита санітарноепідеміологічна ситуація в місті доби Гетьманату та спалах епідемії холери й «іспанки» у 1918 р. В умовах ще слабкої державної влади, війни та німецько-австрійської окупації центральний уряд не залишається осторонь, мобілізуючи організаційні та матеріальні можливості. Одеська міська влада та медичний персонал стають головною силою опору небезпеці, активно використовуючи усі доступні медичні, профілактичні та санітарні заходи.

Ключові слова: Гетьманат, міська преса, епідемія, санітарне просвітництво, вакцинація, місцева влада

Як доводять події сьогоднішнього часу, ми живемо у досить неспокійному та дуже взаємопов'язаному світі, хоч і розділені державними кордонами. До нещодавнього часу явища «епідемія» та «пандемія» здавалися зниклими чи такими, що торкалися якихось занедбаних територій «третього світу». Але рік тому все змінилося: пандемія охопила практично весь світ і не збирається відступати. У зв'язку з цим виникають органічні питання: як розвалися епідемії раніше, як суспільство, у тому числі українське, протидіяло їм і чи можна з цього досвіду щось запозичити?

Актуальність даного питання полягає як у суто історичних аналогіях, що розширюють наше бачення світу, його взаємозалежності та повторювання, а також у практичній площині, як можливість запозичення досвіду поведінки різних соціальних структур, перш за все, місцевої влади й органів самоврядування, в умовах пандемій та епідемій.

Метою дослідження є розкриття, та можливе запозичення, досвіду 1918 р., тобто часів гетьманування П. Скоропадського та австро-угорської окупації України. Така паралель уявляється досить актуальною на підставі схожості ситуації: економічна та соціальна криза, слабкість політичної влади й, у той же час, намагання приймати практичні заходи до упорядкування життя в країні, що було притаманним урядові гетьмана, й одночасно конкретна ступінь залежності країни від іноземних держав і стан гібридної війни (зараз на Сході, у 1918 р. - з більшовиками й ін.). Об'єктом уваги обрано місто Одеса, бо саме тут, як у портовому місті, різні епідемії були досить частими «гостями», й у зв'язку з цим, був накопичений неабиякий досвід боротьби з ними.

Дана розвідка проведена на матеріалах одеської преси, бо саме газета, що виходила щодня, була єдиним засобом оперативної масової інформації на той час та могла донести до мешканців найсвіжіші новини та впливати на психологічний стан мешканців міста (наскільки важливу роль мають засоби масової інформації в умовах масових захворювань населення переконувати нікого зараз не треба!). 
Подіям в Одесі часів громадянського протистояння 1917-1921 рр. присвячений досить великий пласт досліджень. У радянські часи - це загальні роботи про встановлення радянської влади в місті та боротьбу з Центральною радою, урядами П. Скоропадського та Директорії, Антантою й атаманщиною. Роботи істориків останніх десятиліть: 3.В. Першиної, В.Н. Станко, О.А. Раковського й ін. розглядають у цілому історію Одеси як фрагмент загальної історії України періоду громадянської війни ${ }^{1}$. В.Р. Файтельберг-Бланк і В.А. Савченко 2 , В.П. Малахов і Б.А. Степаненко надають фактаж стосовно історичних подій в Одесі, в тому числі і спалаху епідемій та їхнім сумним наслідкам. Чарльз Кінг у популярній формі розкриває знакові події, загальну картину громадянської війни, важкі соціальні й епідеміологічні умови життя, рефлексії уряду П. Скоропадського у намаганні вирішити ситуацію, але не вдається до деталізації ситуацій 4 .

Що стосується саме питання про поширення епідемії холери та «іспанки» у 1918 р., то можна назвати роботи з історії медицини в Україні С.А. Верхратського та П.Ю. Заблудовського 5 , І.Д. Хороша, які присвячені початку формування нової системи охорони здоров'я та проблемам з цим пов'язаних, у тому числі й епідемійб. Питання епідеміологічної ситуації часів П. Скоропадського у регіонах, переважно центральної частини України, розкривається у дослідженнях Л.М. Жванко7. Стосовно описання епідеміологічної ситуації саме в Одесі 1918 р., то можна вказати на праці епідеміолога Л.В. Громашевського ${ }^{8}$, які розкривають питання винятково 3 точки зору медика-епідеміолога.

Таким чином, вітчизняна історична наука має широкий спектр досліджень, де викладені різні проблеми історії періоду громадянського протистояння, урядування Гетьманату та епідеміологічної ситуації в країні у 1918 р. Але аналіз висвітлення епідемії в Одесі у 1918 р. саме на шпальтах газет ще не проводився. Стаття має на меті проаналізувати діяльність різних структур влади - центра й органів самоврядування Одеси в умовах епідемії холери та «іспанки» у 1918 р. та їхнє висвітлення на сторінках місцевої преси.

Епідеміологічні ситуації першої половини XX ст. тривали на теренах Російської імперії з 1902 і до 1925 рр., тобто більше 20 років. На українській території холера поширювалася у 1910, 1915-1916, 1918-1922 рр. Епідемічна ситуація в Українській державі за правління П.Скоропадського залишалася вкрай складною. Протягом літа-осені 1918 р. поряд з уже відомими інфекційними захворюваннями з'явилися нові. Боротьба з ними набула загальнодержавного значення. Події в Україні були

\footnotetext{
${ }^{1}$ Історія Одеси / Гол. ред. В.Н. Станко. Одеса: Друк, 2002. 560 с.

2 Файтельберг-Бланк В.Р., Савченко В.А. Одесса в эпоху войн и революций. 1914-1920. Одесса: Оптимум, 2008. 336 с.

3 Малахов В.П., Степаненко Б.А. Одеса 1900-1920 рр. Люди... Події... Факти... Одеса: Optimum, 2004. $448 \mathrm{c.}$

4 Кинг Ч. Одесса: Величие и смерть города грез. Москва: Изд-во Ольги Морозовой, 2013. 336 с.

5 Верхратський С.А., Заблудовський П.Ю. Історія медицини: навч. посібник. Київ: Вища школа, 1991. $431 \mathrm{c}$.

6 Хорош І.Д. Перші роки становлення радянської охорони здоров'я на Україні (1918-1920). Київ: Медицина, 1963.

7 Жванко Л.М. Соціальні виміри Української Держави (квітень-грудень 1918 р.). Харків: Прапор, 2007. 224 с.; Жванко Л.М. Уряд Павла Скоропадського і спроба подолання епідемій серед населення та біженців // Київська старовина. 2005. № 6. С. 112-125.

8 Громашевский Л.В. Избранные труды. Т. 1: Вопросы развития советского здравоохранения и становления эпидемиологии. Киев: Медицина, 1987. 318 с.
} 
продовженням світових тенденцій. У 1918-1920 рр. світовий характер носила пандемія «іспанки», яка особливо лютувала в Європі. Протягом 1900-1926 рр. тривала шоста пандемія холери. Остання хвиля охопила й Одесу.

Холера 1918-1922 рр. проходила у складній ситуації революції, економічної кризи, загострення суспільних протиріч і непередбаченості завтрашнього дня, притаманних громадянській війні, що охопила Україну.

Слабкість, постійна зміна чи взагалі відсутність державної влади не могли не відбитися на функціонуванні різних соціальних інститутів. Україна стала транзитною територією руху значної кількості людей, що сприяло розвитку та поширенню різних епідемій. У результаті на початок травня 1918 р. губернії української держави були охоплені епідеміями черевного, плямистого тифу, віспи, кору, скарлатини, дизентерії. У Херсонській губернії були зафіксовані випадки холери. Існувала загроза занесення чуми з чорноморських портів і небезпека все ближче підходила до Одеси 9 .

19 квітня 1918 р. на першій сторінці головної міської газети «Одеські новини» величезними літерами було надруковано «Державний переворот на Україні. Обрання генерала Скоропадського» і поруч: «Закони про тимчасовий державний устрій України». А ще через декілька днів газета констатує: «Скрізь, куди ні поглянь - війська, війська, війська. Життєрадісні вулиці завжди галасливого та вічно юного міста були спустошеними та понурими. Публіка кудись подівалася. Втім їі рясно замінили австро-германські патрулі»10.

Нова влада успадкувала досить слабку організацію санітарного обслуговування населення. Напередодні Першої світової війни у губерніях працювали лише 99 санітарних лікарів і 65 санітарних фельдшерів, а в умовах війни та революції суттєво скоротилося й фінансування медичних установ і медичний та санітарний апарат був майже зруйнований. Гетьманат реорганізує структуру місцевої влади, посилюючи її централізацію - у червні 1918 р. був створений головний санітарний департамент - Міністерство народного здоров'я та опікування, який очолив один 3 перших санітарних лікарів України А.В.Корчак-Чепурківський, головною задачею якого стала, перш за все, боротьба з епідеміями. Від міських санітарних органів вимагали у разі появи перших випадків холери негайно телеграфувати в Київ. Про подальшу появу щодня подавати відомості. За декілька днів до лікарських інспекторів, міських управ Києва та Одеси був надісланий спеціальний обіжник, який фактично давав роз'яснення яких заходів треба дотримуватися у цій небезпечній обстановці11.

Одночасно з українськими центральними та місцевими органами санітарії, за доби Гетьманату були створені санітарні структури австро-угорських і німецьких військ. Вони розташувалися і в Одесі, бо епідеміологічна ситуація тут була загрозливою. Невдовзі ситуація в місті суттєво погіршилася, низка заводів були переведені на військові замовлення, багато закриті зовсім. Зростало безробіття (нараховувалося понад 25 тис. безробітних), населенню не вистачало продуктів, вугілля та дров на опалення. Потоками йшли до Німеччини й Австро-Угорщини продовольчі вагони ${ }^{12}$. Окупанти ставили за мету проведення профілактичних заходів серед сво-

\footnotetext{
${ }^{9}$ Ibid. C. 49-51.

10 Маленькие одесские новости. 1918. 20 апреля.

11 Пиріг Р.Я. Діяльність урядів гетьманату Павла Скоропадського: персональний вимір. Київ: Ін-т історії України НАН України, 2016. С. 413.

12 Кінг Ч. Указ. раб. С. 192.
} 
їх військ і не відмовлялися від співробітництва із санітарними структурами української держави. У середині червня 1918 р. одеські санітарні лікарі та санітарна комісія австро-угорського окупаційного корпусу, досягли угоди, відповідно до якої іноземна сторона в разі поширення епідемії мала право через місцеві санітарні органи проводити протиепідемічні заходи серед цивільного населення. Українська сторона, своєю чергою, зобов'язувалася повідомляти австро-угорську санітарну комісію про стан епідемічних захворювань ${ }^{13}$. Занесення холери чекали протягом усього року. Вона рухалася неминуче на Одесу з півночі, де на всій території простежувалися їі дрібні вогнища, більш рішуче загрожувала зі сходу, де вона сильно лютувала. Вона і була принесена спочатку австрійськими окупантами із сільських районів, які прилягали до міста ${ }^{14}$.

Спеціальним напрямком діяльності санітарних служб була організація та проведення на державному рівні широкомасштабної профілактичної роботи по попередженню спалахів інфекційних захворювань. Для цього у складі центрального санітарного департаменту був створений відділ санітарної просвіти. 18 серпня на сторінках газет вперше з'явилося його хвилююче оголошення: «Холерна небезпека. Громадяни, будьте уважними!». Повідомлялося про те, що «в Одесі зафіксували перший випадок холерного захворювання. Хворого ізольовано, він знаходиться під контролем австро-угорського командування. Нових випадків холери поки в місті не було. Був вчора лише один випадок на підозру. Санітарний відділ міської управи з метою боротьби з холерною небезпекою створює в місті низку медичних пунктів. Домовими організаціями буде випускатися «холерна» література» 15.

У цьому ж номері газета надрукувала «Санітарні заповіти», а саме про те, що захворів німецький солдат, але хоч «Час важкий, голодний, але не можна падати духом. Зараза не носиться у повітрі, не всім загрожує. Заразитися може той, хто неохайно ставиться до себе, виснажений чи голодний. Зараза передається через воду, молоко, через продукти, брудний посуд, через контакт із хворими» 16.

Отже, вже з першого дня за ініціативою саме органів місцевого самоврядування були зроблені перші кроки, щоб протидіяти хворобі та не допустити паніки. Одночасно, в межах піклування за власну безпеку, до карантинних заходів долучилися австро-угорські війська. Перший пароплав «Посадник», що зайшов в одеську бухту після 18 серпня, було зупинено на рейді: «До нього підійшла шлюпка, в якій знаходилися представники карантинного догляду та германський і австрійський лікарі. Вони опитали капітана про наявність хворих на борту, лікарі оглянули весь пароплав і пасажирів. Тільки після цих ретельних заходів, які не виявили хворих, кораблю дозволено було пришвартуватися, а пасажирам вийти в місто»17.

Місто взяло ситуацію під ретельний контроль. Через два дні газета інформує схвильованих читачів, що нових випадків захворювань поки що немає. «Місто відбулося легким переляком! Бактеріологи уважно досліджують будь-який підозрілий випадок» ${ }^{18}$.

Але небезпека все ж таки потрапила до міста. На борту пароплава «Олена», який

\footnotetext{
13 Жванко Л.М. Уряд Павла Скоропадського і спроба подолання епідемій... С. 114.

14 Революция на Украине. По мемуарам белых. Москва: Госиздательство, 1930. С. 139.

15 Маленькие одесские новости. 1918. 18 августа.

16 Ibidem.

17 Ibid. 1918. 19 августа

18 Маленькие одесские новости. 1918. 21 августа.
} 
прибув з біженцями з Новоросійська, захворіли двоє пасажирів. «На борт прибули представники карантинної влади, австрійські медичні солдати, які близько нікого не допускали. Пасажири «Олени» мають пройти через баню та дезінфекційну камеру. Їхні речі будуть ретельно дезінфіковані. На берег ніхто з них не спускався. Пароплав «Олена» поставлений біля хвилерізу, де він буде витримувати карантин. На пароплаві проведена ретельна дезінфекція. На ньому підняли карантинний прапор, який свідчить про виявлення холерних захворювань. Дезінфекцію пройшли 299 жінок і дітей та більш ніж 200 чоловіків»19. Безумовно, такий ретельний звіт про стан речей і прийняті заходи, мав, перш за все, одну мету - заспокоїти мешканців міста. Наступного дня газета повідомляла, що серед пасажирів «Олени» одеситів немає. I знову, щоб мати постійний зв'язок з людьми в умовах холерної небезпеки, у Сабанських казармах було розташовано санітарне бюро та встановлено телефонне чергування лікарів з оголошенням номеру «гарячої лінії» 20.

31 вересня місто вступило в смугу епідемії. Щодня на шпальтах газет друкують повідомлення про нові випадки підозри на захворювання чи холерні захворювання у різних районах Одеси: на вулицях Софіївській, Церковній, Новощепному ряду, Картамишевській, на Слобідці... Окремі захворювання були зафіксовані у передмісті: у Кривій Балці, селищі Усатово. Спалах холери відбувся у міській психіатричній лікарні, де захворів, і це «було встановлено бактеріологічно», 71 пацієнт. Хвороба поширювалася та захоплювала все більші райони, де мешкали переважно незаможні люди - Молдаванка, Пересип, Слобідка, і де антисанітарні умови життя створювали чудове підгрунтя для будь-якої епідемії 21.

Основним питанням порядку денного стала організація в місті протихолерних заходів. Запорукою успіху мала стати тісна співпраця відповідних урядових і місцевих органів самоврядування. Ще на початку літа, коли випадки холери почали вибухати по всій Україні, уряд розробив плани ліквідації холери та засоби його практичної реалізації. За умовами плану передбачалося фінансування протиепідемічних заходів з державної скарбниці, у подоланні хвороби, а також у кожній губернії належало здійснити виділення коштів земськими та міськими управами. Одеське самоврядування вирішило просити допомоги 70 тисяч рублів і сподівалося їх отримати, бо Київ запросив кошторис.

Наприкінці вересня в Одесі була створена санітарна комісія на чолі з лікарем М.Н. Леоновим, який завідував хіміко-бактеріологічною лабораторію. Завідуючим дезінфекційної камери стає відомий у майбутньому лікар-епідеміолог, завідувач кафедрою Одеського медичного інституту, організатор санітарно-епідеміологічних станцій в СРСР, Герой Соціалістичної праці Л.В. Громашевський

Для подолання епідемій, у першу чергу, необхідно було налагодити процес масового щеплення населення. Газети починають активно пропагувати цю потребу та пояснюють, що вже в травні Головний медичний департамент надіслав запити на адресу директорів бактеріологічних інститутів Києва, Катеринослава, Одеси, Харкова та Чернігова про можливості та потреби цих установ для виготовлення вакцини та сироваток.

У другій половині вересня газети друкують інформацію про те, що спеціально створені загони лікарів проводять запобіжні щеплення проти холери. Повідом-

\footnotetext{
19 Ibid.1918. 28 августа.

20 Ibid. 1918. 29 августа.

21 Маленькие одесские новости. 1918. 11 сентября.
} 
лення про те, що «щеплення цілком безпечні та не несуть ніякої шкоди. Вони є добрим попереджувальним заходом від захворювання. За повідомленням професора Златогорського, на кожну тисячу щеплених на холеру, захворіло лише 19, а померло 2; на кожну тисячу нещеплених захворіло 97 і померло 69 чоловік» переконували людей. Щоб ще раз підкреслити необхідність щеплень, санітарні лікарі через газету доводять на прикладах «...блискучі результати щеплень на Волзі, у Катеринославлі, Астрахані. У Греції серед щеплених солдат захворіло лише 7 чоловік на тисячу, а серед нещеплених захворіли 93 на тисячу». Інформація закінчувалася закликом: «Йдіть до своїх дільничних лікарів і щеплюйтесь!»22.

Щоб зберегти лікарів, саме їм першим були зроблені щеплення, а також тим, від кого залежало нормальне функціонування міста - всьому персоналу міської пральні, хлібопекарні, сирітського притулку, робітникам міського водогону та прикордонникам. Жоден не захворів на холеру! ${ }^{23}$.

Але перший етап протиепідемічних заходів проходив дуже непросто: міська санітарна комісія постійно збиралася й обговорювала проблеми, що виникали при масовому щеплені. «Населення околиць, - скаржилися лікарі, - темне та невігласне, ставиться до щеплень насторожено та вороже. Недовірливе ставлення навіть до міських загонів по щепленню. Персонал пральні на Слобідці навіть вимагав замість щеплення дати їм хліба та продуктів. Робітники в один голос стверджували: «Нікому ваші щеплення не допоможуть, у нас не вистачає хліба, ми голодуємо та змушені годуватися помідорами!». У деяких будинках на Слобідці лікарі були змушені годинами переконувати людей і на собі демонструвати безпеку антихолерної вакцини ${ }^{24}$.

Саме необізнаність населення часто ставала причиною протидії вакцинації. Тому постала необхідність проведення роз'яснення суті хвороб, умов їх поширення, способів запобігання. Санітарне бюро при міській управі створило лекційну комісію та виділило невеликі кошти для читання спеціальних лекцій серед населення. Але лікарі згодні були виступати і безкоштовно, аби був результат. Першу безкоштовну лекцію про холеру прочитав на Слобідці доктор Мисиков, другу, в приміщені народної аудиторії, прочитав професор Блауберг. Наступні лекції планували виступи професорів і дільничних лікарів ${ }^{25}$. Але проблема постала у тому, що майже неможливо було зібрати людей на ці лекції. Лікарі обирали місця, куди стікалися громадяни - театри, кіно і, навіть, молитовні заклади, по суботам у синагогах, і читали лекції. У жовтні 1918 р. група лікарів організувала видавництво листівок «Гігієна», метою чого було поширення серед широкого громадського загалу санітарно-гігієнічних знань про інфекційні захворювання та епідемії.

В умовах збільшення кількості хворих загострилася проблема їхньої локалізації. Головною причиною стала нестача лікарень та їхня непридатність для лікування заразних людей, тим більше, що була вже осінь. «Деякі лікарні змушені будуть зачинитися! Які наслідки це може мати зараз, в умовах епідемії!? - обурювалися журналісти. Позбавлені палива й освітлення напередодні зими чи зможуть вони працювати?»26.

\footnotetext{
22 Маленькие одесские новости. 1918. 12 октября.

23 Ibid. 1918. 24 октября.

24 Ibid. 1918. 26 сентября.

25 Маленькие одесские новости. 1918. 4 октября.

26 Ibid. 1918. 12 октября.
} 
Мешканці міста не залишалися осторонь проблем, бо, зрозуміло, ситуація торкалася всіх: була, наприклад, створена екстрена комісія по наданню матеріальної допомоги єврейській лікарні. Проводили «кружечний збір» грошей. По різним районам міста 400 чоловік зі студентської молоді, медичних сестер, єврейських благодійних організацій i, навіть, українських солдатів висловили бажання допомогти збирати кошти. «Єврейська лікарня лікує всіх!» - таким було гасло. Благодійницькі аукціони проходили в дорогому і дуже популярному в Одесі кафе Фанконі, у театрі опери та балету 27.

Схоже кризове становище склалося і в старій міській лікарні. Старший лікар цієї лікарні звернувся із заявою до міської управи про критичне положення у цьому медичному закладі: не вистачало життєво необхідних речей, як продуктових, так і білизни, дров. Палати не опалювалися і з початком морозів хворі ризикували замерзнути на своїх ліжках. Міська управа обіцяла в екстреному порядку розглянути пропозицію лікаря та сприяти проведенню, за прикладом єврейської лікарні, збору грошей серед населення Одеси для старої міської лікарні 28.

Щодня газети друкували повідомлення про епідеміологічну ситуацію, кількість захворілих і тих, хто одужав чи помер. Поступово цифра захворілих зменшується, коливається троє чи четверо на добу, а 1 листопада був зафіксований лише один випадок на підозру.

Але на початку жовтня нова небезпека: бельгійське трамвайне товариство повідомило управу, що 25\% трамвайних працівників захворіло на «іспанку», через декілька днів на міській телефонній станції захворіло більше 60 осіб29.

Санітарно-лікарняна організація міської управи зібрала екстрену нараду, на яку були запрошені представники медичних, наукових і громадських організацій, санітарного опікунства. Метою зібрання було провести роз'яснювальну роботу серед різних верств населення міста про стан нового захворювання та засоби протидії йому ${ }^{30}$.

Учасники наради схвалили кошторис фінансування заходів по боротьбі з новою епідемією, який згодом був переданий на розгляд Ради Міністрів Української Держави. Проте, спеціальних асигнувань на боротьбу з «іспанкою» уряд так і не виділив. Всі видатки на ліквідацію епідемії взяло на себе місцеве самоврядування. Через декілька днів у залі приміщення станції «Швидкої допомоги» знову збирають одеських лікарів для обміну досвідом про хід поширення епідемії, про нові, ще невідомі приклади прояву захворювання 31 . Хвороба поширювалася, охоплюючи місця скупчення людей і ті, де було погане провітрювання. Лікарі скаржилися, що лікарю важко навіть оглянути хворого, настільки у кімнатах важке повітря. «Люди бояться свіжого повітря!»32.

«Товариство одеських лікарів» зібралося на обговорення питання про «іспанку» та висловило тверде переконання, яке через газету було доведено до населення, що при дотриманні конкретних заходів безпеки та загальних кроків з боку міського керівництва, хворобу швидко вдасться припинити. «Тривоги і страхів у публіки

\footnotetext{
27 Ibid. 1918. 29 сентября.

28 Маленькие одесские новости. 1918. 10 ноября.

29 Ibid. 1918. 10 ноября.

30 Ibid. 1918. 29 сентября.

31 Ibid. 1918. 4 октября.

32 Одесский листок. 1918. 11 октября.
} 
немає бути, - доводили лікарі. Дуже небезпечним є аерофобія у багатьох людей (навіть інтелігентних прошарків), коли у квартирах зачиняють усі вікна та кватирки. Ніщо так не сприяє боротьбі з епідеміями, як свіже повітря!»33.

В умовах поширення будь-якої епідемії питання санітарного стану зони небезпеки, а також якість харчування людей, які мешкають у цих районах, розглядалися спеціалістами як неабиякий засіб боротьби з небезпекою зараження. Місто Одеса взяло під свій спеціальний контроль санітарний стан будинків в одному 3 найбільш епідеміологічно небезпечному районі Одеси - на Слобідці та «провело очистку домівок від нечистот». Тут же, на Слобідці, міська управа відкрила безкоштовний пункт харчування для її мешканців. Щодня годували 250 чоловік. Видавалася гаряча їжа, пів фунта хліба, окріп. «Цю справу треба поширювати тому, що погане харчування мешканців Слобідки, охопленою епідемією, загрожує лихом усьому місту. Щоб не скупчувати людей в одному місці і не розносити заразу, їжу розвозять по домах» ${ }^{34}$.

Одеські лікарі звертали увагу, як на дуже серйозну проблему, запобігання поширенню епідемій у місті, на проблему водопостачання води до різних районів міста, особливо у жаркі літні місяці. А проблема була: «В усіх районах міста послаблюється тиск води у водогоні. У багатьох місцях води немає взагалі. В особливо важкому стані опинилися мешканці центру міста, в районі лютеранської кірхи. Тут три дні повністю відсутня вода і мешканці змушені йти за водою на сусідню вулицю. Протягом трьох днів не прибирається сміття, поширюється сморід. I це в умовах холерної епідемії!»35.

Епідемія в Одесі продовжувалася до середини листопада. Було зафіксовано 221 бактеріологічно встановлений випадок захворювання. Боротьба з епідемією була проведена досить успішно. Епідемія майже не вийшла за межі одного району міста - Слобідки ${ }^{36}$.

Одиничні випадки захворювань газети фіксували ще протягом листопада. Хвиля епідемії 1918 р. відійшла, щоб підніматися у наступні роки. Незважаючи на те, що повністю ліквідувати епідемію холери та «іспанки» за доби Гетьманату не вдалося, були вжиті максимум можливих на той момент заходів: створено головний санітарний департамент, на який покладали завдання боротьби 3 епідеміями, 3 державного бюджету виділялися, хоч і невеликі, кошти на протиепідемічні заходи та формування мережі відповідних спеціалізованих закладів.

Зміна політичної влади в Україні наприкінці 1918 р. ускладнила плани повного подолання епідемій холери, «іспанки» й інших хвороб. Постійним провокаційним фактором поширення захворювань були біженці, які рухалися в Одесу та одеський порт.

На шпальтах одеської преси розгортання епідемії у місті та заходи боротьби 3 нею знайшли об'єктивне, досить критичне і, в той же час, небайдуже висвітлення. Переважна увага приділялася діяльності органів місцевого самоврядування, санітарно-епідеміологічних закладів Одеси, медичних робітників і патріотично налаштованих одеситів, які самовіддано боролися з небезпекою.

Спроба провести історичні паралелі та запозичити досвід для його використан-

\footnotetext{
33 Ibid. 1918. 19 октября.

34 Ibid. 1918. 21 октября.

35 Маленькие одесские новости. 1918. 11 сентября.

36 Громашевський Л.В. Вопросы развития советского здравоохранения... С. 52.
} 
ня у сучасній епідеміологічній ситуації, дозволяє зробити наступний висновок: самовідданістю і чесністю влада та лікарі досягли довіри населення, і через довіру до дій влади зуміли подолати страх перед небезпекою і, як наслідок, подолати епідемію. Саме ці фактори і на сьогоднішній день виступають важливим чинником боротьби з викликом світової пандемії.

\section{REFERENCES}

Alekseev, S.A. (Comp.) (1930). Revoliutsiia na Ukraine. Po memuaram belykh [Revolution in Ukraine. According to the memoirs of 'whites']. Moskva-Leningrad: Gosizdatelstvo [in Russian].

Faitelberg-Blank, V.R. \& Savchenko, V.A. (2008). Odessa v epokhu voin i revoliutsii. 1914-1920 [Odessa in the era of wars and revolutions. 1914-1920]. Odessa: Optimum [in Russian].

Gromashevskiy, L.V. (1987). Voprosy razvitiya sovetskogo zdravookhraneniya i stanovleniya epidemiologii [Questions of the development of Soviet health care and the formation of epidemiology]. Kiev: Meditsyna [in Russian].

Khorosh, I.D. (1963). Pershi roky stanovlennia radianskoi okhorony zdorovia na Ukraini (1918-1920) [The first years of the formation of Soviet health care in Ukraine (1918-1920)]. Kyiv: Medytsyna [in Ukrainian].

King Charles (2013). Odessa: Velichie i smert goroda griez [Odessa. Genius and Death in a City of Dreams]. Moskva: Izd-vo Olgi Morozovoi [in Russian].

Malakhov, V.P. \& Stepanenko, B.A. (2004). Odesa 1900-1920 rr. Liudy... Podii... Fakty... [Odesa 19001920. People... Events... Facts...]. Odesa: Optimum [in Ukrainian].

Pyrih, R.Ya. (2016). Diialnist uriadiv hetmanatu Pavla Skoropadskoho: personalnyi vymir [Activities of the governments of the Hetmanate of Pavel Skoropadsky: personal dimension]. Kyiv: In-t istorii Ukrainy NAN Ukrainy [in Ukrainian].

Stanko, V.N. (Ed.) (2002). Istoriia Odesy [The History of Odessa] Odesa: Druk [in Ukrainian].

Verkhratskyi, S.A. \& Zabludovskyi, P.Yu. (1991). Istoriia medytsyny [The History of Medicine]. Kyiv: Vyshcha shkola [in Ukrainian].

Zhvanko, L.M. (2005). Uriad Pavla Skoropadskoho i sproba podolannia epidemii sered naselennia ta bizhentsiv [The government of Pavel Skoropadsky and an attempt to overcome epidemics among the population and refugees]. Kyivska starovyna, 6, 112-125 [in Ukrainian].

Zhvanko, L.M. (2007). Sotsialni vymiry Ukrainskoi Derzhavy (kviten - hruden 1918 r.) [Social dimensions of the Ukrainian State (April - December 1918)]. Kharkiv: Prapor [in Ukrainian].

\section{Halyna Kiazymova}

(Odessa National Maritime University, Odessa, Ukraine)

e-mail: sineva2009@gmail.com

ORCID: https://orcid.org/0000-0001-7453-015X

\section{Epidemiological situation in Odessa under the Hetmanate (according to materials from Odesa newspapers of 1918)}

Today pandemic occupied almost all the world. It is still a serious problem for population. A lot of countries have already faced this challenge at various times. In a result they found the solutions. Using of the previous experience and developing new ways are the keys to successful overcoming modern pandemic.

The goal of this exploration is clarification of the epidemiological situation and methods of solving the problem in Odessa in 1918. That is why we should draw parallels between the current international, socio-political and economic situation in Ukraine and the era of the Hetmanate. It will be useful to benefit from the fight against the epidemic during the reign of Pavlo Skoropadskyi.

We explored local press of 1918 , because it was the main way of rapid informing the population and influence on local residents. That is how governments communicated with inhabitants of Odessa.

In the context of cholera and then Spanish flu, local authorities and medicals acted 
promptly. All people who become ill went into isolation. There were rooms for isolation and choleric barracks in the hospitals. They conducted a thoroughly search of the ships, that went into a port. The sanitary situation was seriously controlled in the most epidemiologically dangerous parts of the city. There even was free food for people.

Vaccination campaign was the main aim. But the population didn't trust it. Local authority, sanitarians employed a huge propaganda of necessity and effectiveness of vaccine.

The wave of epidemic was stopped in 1918. Local authority, brave doctors and selfless residents impacted on overcoming this pandemic the most. Nowadays these aspects are important too.

Keywords: the Hetmanate, local press, epidemic, local authority, sanitary enlihtement, vaccination 